\section{Blogs on education: Examination of teachers' use cases and thoughts}

\section{Eğitim ile ilgili bloglar: Öğretmenlerin kullanım durumları ve düşüncelerinin incelenmesi}

\author{
Nagihan Tepe ${ }^{1}$
}

\section{Özet}

$\mathrm{Bu}$ araşturmada amaç öğretmenlerin eğitim ile ilgili blogları kullanım durumları ile bu bloglar hakkındaki görüşlerini incelemektir. Nitel araştırma desenlerinden olgu bilim desenine göre yürütülen çalışmanın araştırma grubunu 22 öğretmen oluşturmaktadır. Veriler, araştırmacı tarafindan geliştirilen yarı yapılandırılmış görüşme formu aracillŏıyla toplanmıştır. Elde edilen veriler betimsel analiz tekniği ile incelenerek; frekans ve tablolar ile sunulmuştur. Araştırmanın bulgularına göre öğretmenlerin tamamına yakını eğitim ile ilgili en az bir blog takip etmektedir. En çok takip edilen bloglar; "egitimbane", "egitimpedia", "vitaminogretmen" olarak belirlenmiştir. $\mathrm{Bu}$ blogları öğretmenlerin takip etme sıklığ çoğunlukla haftada bir kaç gündür. Öğretmenler bloglar dışında sosyal medyadan da kendi branşları ile ilgili içeriklerin yer aldığı gruplar1 takip etmektedirler. Öğretmenlerin büyük çoğunluğu eğitim ile ilgili herhangi bir basilı yayın takip etmediklerini ifade etmişlerdir. Katılımcıların eğitim ile ilgili blogları kullanım amaçları sorulduğunda çoğunlukla öğrencilerine ödev-proje vs konusu belirlemek için, yıllıkgünlük plan hazırlamak için, alanı ve mesleği ile ilgili güncel gelişmeleri takip edebilmek için ve sınav soruları oluşturmak için takip ettikleri görülmüştür. Öğretmenler, eğitim ile ilgili blogların kendilerine sağladığı katkıları; zengin

\footnotetext{
1 Dr. Öğr. Üyesi, Samsun Üniversitesi, İktisadi, İdari ve Sosyal Bilimler Fakültesi, İletişim Tasarımı ve Yönetimi Bölümü, tepenagihan@gmail.com
} 
Tepe, N. (2020). Eğitim ile ilgili bloglar: Öğretmenlerin kullanım durumları ve düşüncelerinin incelenmesi. Journal of Human Sciences, 17(1), 162-171. doi:10.14687/jhs.v17i1.5766

leading to theft of labor, causing the feeling of imposing ideas, and students' access to exam questions.

Keywords: Blog, education, internet, teacher, qualitative research.

(Extended English summary is at the end of this document) içerik deposu olması, fikir paylaşımına imkan vermesi, güncellik sağlaması, bilgiye ulaşım kolaylı̆̆ı, kişisel gelişime katkı sağlaması, iletişimi kolaylaştırması, motivasyon kaynağı olması ve zaman tasarrufu sağlaması olarak ifade etmişlerdir. Öte yandan hazırcılığa alışturması, bilgi kirliliğine yol açması, üreticiliği sıfirlaması, emek hırsızlığına yol açması, fikir dayatması hissine sebep olması ve öğrencilerin sinav sorulanna ulaşabilmesi gibi faktörler ise öğretmenler tarafindan blogların olumsuz özellikleri olarak ifade edilmiştir.

Anahtar Kelimeler: Blog, eğitim, internet, öğretmen, nitel araştırma.

\section{Giriş}

Her geçen gün internet kullanımının daha da yaygınlaşması ile dünya çapında insanlar arası iletişim biçiminin değişerek farklı boyutlarda gerçekleştiği görülmektedir. Bu gelişme sadece insanlar arası iletişimi değil, insanların bilgiye ulaşma ve sahip olduğu bilgiyi paylaşma şekillerini de değiştirmiştir.

İnternetin yeni yüzü olarak adlandırılan ve bu yeniliklerden biri olan Web 2.0 teknolojileri kelimeler, görseller ve ses dosyaları ile çift taraflı ve eş zamanlı bilgi paylaşımına ulaşılmasını sağlayan şemsiye bir kavramdır (Öztürk, Öztürk ve Özen, 2016). Bu ortam herkesin dilediği konuda içerik oluşturabilmesine, etkileşimli siteler yaratabilmesine, yazıll, görüntülü ve sesli çeşitli materyaller paylaşmasına imkan tanır (Özüdoğru, 2014). Web 2.0 teknolojileri sosyal paylaşım siteleri, video paylaşım siteleri, vikiler, bloglar ve ortaklaşa ya da paylaşarak oluşturulan bir sinıflandırma biçimi olan folksonomileri içerir (Madge, Meek, Wellens \& Hooley, 2009). Bu araştırmanın konusu günümüzde yaygın olarak kullanılan bloglar ile ilgili kısmı kapsamaktadır.

En basit ifade şekliyle blog, günlük biçiminde kişisel bir giriş sayfasıdır (O'Reilly, 2007). Elektronik bir günlüğe benzeyen bloglar okuyucuların fikirlerini ve görüşlerini paylaşabildiği bir ortam olarak tanımlanmaktadır (Lewis, 2009). İnsanların iletişim kurması için bir tür sosyal araç olan bloglar (Baker and Moore, 2008), internet tabanlı olan e- posta veya diğer bazı paylaşım siteleri gibi bir veya birkaç kişinin birçok kişiye ulaşmasını değil birçok kişinin birçok kişiye ulaşmasını sağlamaktadır (Dinçer, Çakmak ve Aydoğan-Çiftçi, 2019).

Konularına göre çeşitli alanlarda oluşturulabilen bloglar, zengin içerikleri ile kısa sürede okuyucuların sorularına cevap verebilecek özelliktedir. Bloglar bu özelliği ile okumayı ve yazmayı seven kişiler için ücretsiz, çevrimiçi bir yayınevi niteliği taşımaktadır (Ward, 2004). Ortak noktalarda buluşabilen insanlar için çift yönlü etkileşimin gerçekleşebileceği bir sosyal platform olarak nitelendirilebilen bloglar belli konular üzerinde okuyarak, düşüncelerini ifade etmeye, yorumlar yapmaya ve karşıllklı fikir alısverişinde bulunmaya imkan tanır. Efimova (2009)'ya göre bloglar düşünceleri birleştirme ve sınıflandırma, aynı konularla ilgilenen kişilerle bağlantı kurarak işbirliği oluşturma ve başka blog yazarları ile ilişkileri geliştirme, araştırma yapma veya bir yayın üzerinde çalışmaya yardımcı olmaktadır.

Blogların internette büyümesi olağanüstü bir hızla ilerlemektedir. Başlangıçta kullanıcılarının kendi çevrimiçi kayıtlarını takip etmeye yardımcı olan bloglar zamanla çevrimiçi kültürün önemli bir parçası haline gelmiştir. Bu yöntemle ortalama bir insan tartşmak istediği herhangi bir konunun materyalini kolaylıkla yayınlayabilmektedir. Popüler bir mesele ile ilgili bir blog dikkatleri çekerek toplumlar üzerinde büyük etkiler oluşturabilmektedir (Hsu \& Lin, 2008).

Günümüzde bloglar hem toplumsal yaşamla ilgili gündelik konularda, hem de çalışma yaşamı ile ilgili profesyonel ve mesleki konularda yaygın bir şekilde kullanılmaktadır. Özellikle 
Tepe, N. (2020). Eğitim ile ilgili bloglar: Öğretmenlerin kullanım durumları ve düşüncelerinin incelenmesi. Journal of Human Sciences, 17(1), 162-171. doi:10.14687/jhs.v17i1.5766

profesyonel yazarlar tarafindan çalışma yaşamı ile ilgili mesleki konularda yazılan bloglar, bilgi ile tecrübeyi bütünleştiren ve anlatım dili olarak da daha sade ve anlaşlır bir dilin hakim olduğu bilgi kaynakları olarak kullanılmaktadır (Seçer, 2017).

Bilgi ve tecrübe paylaşımlarının yapıldığı; okul, öğrenci, aile, veli, ders içerikleri, eğitim alanındaki güncel gelişmeler ve eğitim-öğretim ile ilgili diğer konularda materyallerin yayınlandığ1 diğer bir alan ise içeriği eğitim ile ilgili olan bloglardır. Bu bloglar öğretmenler, yöneticiler, veliler ve hatta öğrenciler için zengin bir bilgi kaynağıdır. Eğitim ile ilgili bloglar bu bağlamda kullanıcılarına güncel bilgilere kolay ve hızlı ulaşabilme imkanı sunar, iş birliğini geliştirir, farklı fikirlere bakış açısı kazandırır, öz değerlendirme yapabilme firsatı verir. Hargreaves (2002)'a göre eğitimsel anlamda ağlar, değişimi ve değişimin sürdürülebilirliğini desteklemekte, kullanıcıların internet yoluyla bağlandığ1 sosyal ve profesyonel ağlar etkileşim ve bilgi paylaşımı yoluyla birbirlerine bağlanmakta ve zaman içerisinde bu durum profesyonel bir desteğe dönüşebilmektedir.

Blogların eğitimde kullanıldığı bazı yerler şunlardır; kişilerin eğitim-öğretim tecrübelerini yansıtır, kaynaklar ve yöntemler ile ilgili sınıflandırılmış açıklamalar içerir, mesleki zorluklar ile ilgili çıkıs noktaları sunar, teknoloji hakkında ipuçları içerir, etkinlikler, ödevler ve kaynaklarla ilgili çevrimiçi bir kaynak deposudur, ve öğrencilerin değerlendirilmesi ile ilgili çevrimiçi bir alandır (Duffy \& Bruns, 2006). Literatür incelendiğinde turizm ile ilgili blogların incelendiği (Dinçer ve Çakmak, 2019), yabancı dil eğitiminde blogların kullanımı (Moralı, 2018; Türker ve Genç, 2018), insan kaynakları ile ilgili blogların incelendiği (Seçer, 2017) konularında çalışmalar yapıldığı görülmektedir. Duffy \& Bruns (2006) ise eğitimde blogların kullanımı ile ilgili bir araşturma yapmışlardır. Ulusal literatürde, etki değeri büyük ve kullanım alanı geniş olan eğitim içerikli bloglar hakkında çalışmaya rastlanmamış olması bu konuya ilişkin araştırma ihtiyacını doğurmuştur. Bu amaçla araşturmada öğretmenlerin eğitim ile ilgili blogları kullanım durumları ve bu bloglar hakkındaki görüşlerinin incelenmesi amaçlanmıştır.

\section{Yöntem}

\subsection{Araştırma Deseni}

Bu çalışmada nitel araştırma desenlerinden biri olan olgu bilim deseni kullanılmıştır. Olgu bilim, aslında farkında olunan fakat derinlemesine ve ayrıntılı bir şekilde anlayışa sahip olmadığımız olgulara odaklanmayı amaçlamaktadır (Yıldırım \& Şımşek, 2008).

\section{2. Çalışma Grubu}

Çalışma grubunu oluşturan katılımcılar, kolaylık ve maliyet bakımından örnekleme alınacak sınırlı sayıda durumlardan en fazla bilgi alınabileceklerin stratejik olarak seçilmesi ile ulaşılabilir durum örneklemesine uygun olarak belirlenmiştir (Patton, 2014). Katılımcıların 12'si kadın, 10'u erkek olup; yaşları 22 ile 40 arasında değişmektedir. Mesleki kıdemleri en düşük 0-5 yıl arası olup, en yüksek 16-20 yıldır. Branşlarına göre okul öncesi öğretmeni $(n=1)$, sınıf öğretmeni $(n=10)$ ve branş öğretmeni ( $\mathrm{n}=11)$ şeklinde sinıflandırılmaktadır. Öğretmenlerin tamamına yakını lisans mezunu olup yalnızca bir öğretmen yüksek lisans yapmıştır.

\subsection{Verilerin Toplanması ve Analizi}

Veriler, çalışma kapsamında araştırmacı tarafindan geliştirilen yarı yapılandırılmış görüşme formu kullanılarak toplanmıştır. Veri toplama aracı hazırlanmadan önce alanla ilgili literatür taraması yapılarak madde havuzu oluşturulmuştur. Bu maddelerden konu ile ilgili olanlar ayıklanarak kalan maddelerden oluşturulan taslak form bir eğitim bilimleri uzmanına, iki öğretmene ve bir Türk Dili ve Edebiyatı uzmanına inceletilmiştir. İncelemeler sonucunda veri toplama formunda katılımcıların kişisel bilgilerini belirlemeye yönelik 5 soru, eğitim içerikli bloglar hakkındaki görüşlerini belirlemek için ise 8 soru yer almıştır. Bu soruların 3'ü çok seçenekli, 5'i ise açık uçlu sorulardır. Hazırlanan form çalışma grubunda yer alan öğretmenlere e-posta ile gönderilerek görüşleri alınmıştır.

Araştırma kapsamında elde edilen veriler nitel araştırmalarda kullanılan ve verilerin okuyucuya sistematik ve açık bir şekilde betimlenerek sunulmasını amaçlayan betimsel analiz tekniği 
Tepe, N. (2020). Eğitim ile ilgili bloglar: Öğretmenlerin kullanım durumları ve düşüncelerinin incelenmesi. Journal of Human Sciences, 17(1), 162-171. doi:10.14687/jhs.v17i1.5766

(Yıldırım \& Şimşek, 2008) ile incelenerek; frekans ve tablolar ile sunulmuştur. Katllımcıların görüşleri Ö1, Ö2 şeklinde kodlanarak araştırmanın güvenirliğini artırmak amacıyla doğrudan alıntılar şeklinde sunulmuştur.

\section{Bulgular}

\section{1. Öğretmenlerin eğitim ile ilgili herhangi bir blog takip etme durumuna ilişkin verilerin incelenmesi}

Araştırma grubundaki öğretmenlerin tamamına yakını ( $n=21)$ eğitim ile ilgili çeşitli blogları takip ettiklerini ifade etmişlerdir. Yalnızca bir öğretmen herhangi bir blog takip etmediğini belirtmiştir. Bunun sebebi sorulduğunda "branşlara göre sistematik bir gruplandirma olmadiğ için" takip etmediğini ifade etmiştir.

\section{2. Öğretmenlerin eğitim ile ilgili hangi blogları takip ettiğine ilişkin verilerin incelenmesi}

Öğretmenlerin eğitim ile ilgili takip ettiği blogların hangileri olduğu aşağıda Tablo1'de verilmiştir.

Tablo 1. Eğitim ile ilgili takip edilen bloglar

\begin{tabular}{ll}
\hline Blog Ísimleri & n \\
\hline egitimhane & 20 \\
egitimpedia & 6 \\
vitaminögretmen & 5 \\
ilkokul1 & 3 \\
Morpakampus & 3 \\
egitimreformugirisimi & 1 \\
bilgeceingilizceweebly & 1 \\
ilkokulingilizce & 1 \\
eltarena & 1 \\
sosyalbilgiler & 1 \\
okulistik & 1 \\
ogretmenevde & 1 \\
\hline
\end{tabular}

Öğretmenlerin takip ettiği eğitim ile ilgili blogların neler olduğuna dair Tablo 1 incelendiğinde katılımcıların tamamına yakınının ( $\mathrm{n}=20)$ "egitimbane" adlı blogu takip ettiği görülmektedir. "egitimpedia" adlı blog altı katılımcı tarafindan takip edilmekteyken, beş katılımc1 "vitaminogretmen" adlı blogu takip ettiğini belirtmiştir. "ilkokul1" ve "morpakampus" adlı bloglar üçer katılımcı tarafindan takip edilmektedir. Bunun dişında "egitimreformugirisimi", "sosyalbilgiler", "okulistik"," ogretmenevde" adlı blogların da takip edildiği görülmektedir. İngilizce kaynaklı olan "bilgeceingilizceweebly", "ilkokulingiliz̨ce" ve "eltarena" bloglar da katıllmcıların takip ettiği bloglar arasında yer almaktadır.

\section{3. Öğretmenlerin eğitim ile ilgili bloglan hangi sıklıkta takip ettiğine ilişkin verilerin incelenmesi}

Aşağıda Tablo 2'de öğretmenlerin eğitim ile ilgili blogları hangi sıklıkta takip ettiklerine ilişkin veriler yer almaktadır.

Aşağıda Tablo 2 incelendiğinde öğretmenlerin eğitim ile ilgili blogları çoğunlukla ( $n=10)$ haftada birkaç gün inceledikleri görülmektedir. Ayrıca 4 öğretmen her gün ve 2 öğretmen ise ayda bir gün incelediklerini ifade etmişlerdir. Haftada bir ve 15 günde bir incelediğini belirten ise 3 öğretmen bulunmaktadır. 
Tepe, N. (2020). Eğitim ile ilgili bloglar: Öğretmenlerin kullanım durumları ve düşüncelerinin incelenmesi. Journal of Human Sciences, 17(1), 162-171. doi:10.14687/jhs.v17i1.5766

Tablo 2. Eğitim ile ilgili blogların takip edilme sılklğg1

\begin{tabular}{ll}
\hline Zaman aralı̆̆ & $\boldsymbol{n}$ \\
\hline Her gün & 4 \\
Haftada birkaç gün & 10 \\
Haftada bir & 3 \\
15 günde bir & 3 \\
Ayda bir & 2 \\
\hline
\end{tabular}

\section{4. Öğretmenlerin bloglar dişında sosyal medyadan takip ettiği grupların özelliklerine ilişkin verilerin incelenmesi}

Öğretmenlere bloglar dışında sosyal medya hesaplarından eğitim ile ilgili herhangi bir grubu takip edip etmedikleri sorulduğunda 13 kişi evet cevabını verirken, 9 kişi ise herhangi bir grup takip etmediğini ifade etmiştir. Öğretmenlerin sosyal medyadan takip ettikleri eğitim ile ilgili grupların özelliklerine dair verilere Tablo 3 'te yer verilmiştir.

Tablo 3. Sosyal medyadan takip edilen grupların özellikleri

\begin{tabular}{ll}
\hline$\ddot{O}$ zellikler & $\boldsymbol{n}$ \\
\hline Branşla ilgili gruplar & 11 \\
Görsel materyal içerikli gruplar & 1 \\
Okuma-yazma eğitimi & 1 \\
Eğitim sistemi & 1 \\
Blogların sosyal medya hesapları & 1 \\
\hline
\end{tabular}

Tablo 3'e göre 11 öğretmen kendi branșı ile ilgili sosyal medya gruplarm takip ettiğini belirtmiștir. Ayrıca görsel materyal içerikli gruplar $(\mathrm{n}=1)$, okuma-yaz̧ma eğitimi ile ilgili gruplar $(\mathrm{n}=1)$, eğitim sistemi ile ilgili gruplar ( $\mathrm{n}=1$ ) ve takip edilen bloglarn sosyal medya hesaplarmm $(\mathrm{n}=1)$ da takip edilen grupların özellikleri arasında olduğu söylenebilir.

\section{5. Ö ğretmenlerin eğitim ile ilgili herhangi bir basılı yayın takip etme durumuna ilişkin verilerin incelenmesi}

Katılımcıların 8’i eğitim ile ilgili çeşitli basılı yayınları takip ettiklerini ifade ederken, 14 katılımcı ise herhangi bir basılı yayın takip etmediğini belirtmiştir. Branşla ilgili dergiler ( $n=4)$, bilim çocuk dergileri $(n=2)$, Türk. Dili Dergisi $(n=1)$ ve akademisyenlerin yazmış olduğu kitaplar $(n=1)$ takip edilen basılı yayınlar arasında yer almaktadır.

\section{6. Öğretmenlerin eğitim ile ilgili blogları kullanım amaçlarına ilişkin verilerin incelenmesi}

Öğretmenlerin eğitim ile ilgili blogları kullanım amaçlarına ilişkin veriler aşağıda Tablo 4'te yer almaktadır.

Tablo 4. Eğitim ile ilgili blogların kullanım amaçları

\begin{tabular}{|c|c|}
\hline Kullanim amaci & $n$ \\
\hline Ögrrencilerime ödev-proje vs konusu belirlemek için & 17 \\
\hline Yallk-günlük plan hą̧rlamak için & 15 \\
\hline Alanumla ve mesleğimle ilgili güncel gelismeleri takip etmek için & 14 \\
\hline Sinav sorular olusturmak için & 11 \\
\hline Kendi bilgi ve birikimimi paylassmak için & 3 \\
\hline Vakit geçirmek iģin & 2 \\
\hline Arkadaşlarm yönlendirdiğ için & 1 \\
\hline
\end{tabular}


Tepe, N. (2020). Eğitim ile ilgili bloglar: Öğretmenlerin kullanım durumları ve düşüncelerinin incelenmesi. Journal of Human Sciences, 17(1), 162-171. doi:10.14687/jhs.v17i1.5766

Katılımcıların eğitim ile ilgili blogları kullanım amaçlarına ilişkin Tablo 4 incelendiğinde öğretmenlerin çoğunlukla ögrencilerine ödev-proje vs konusu belirlemek için $(n=17)$, yullı-günlük plan bažrlamak için (n=15), alan ve mesleği ile ilgili güncel gelismeleri takip edebilmek için $(n=14)$ ve sinav sorular oluşturmak için ( $n=11)$ blogları takip ettikleri görülmektedir. Ayrıca üç öğretmen bilgi ve birikimini paylaşmak için 2 kişi vakit geçirmek için ve 1 tanesi ise arkadaşlar yönlendirdiği için bloglant takip ettiklerini ifade etmişlerdir.

\section{7. Öğretmenlerin eğitim ile ilgili blogların katkılarına ilişkin düşüncelerinin incelenmesi}

Öğretmenlerin tamamı eğitim ile ilgili blogların gerekli olduğunu ifade etmişlerdir. Aşağıda Tablo 5'te öğretmenlerin bu konudaki düşüncelerine yer verilmiştir.

Tablo 5. Eğitim ile ilgili blogların katkıları

\begin{tabular}{ll}
\hline Katkılar & $\boldsymbol{n}$ \\
\hline Zengin içerik deposudur & 11 \\
Fikir paylaşımı sağlar & 11 \\
Güncellik sağlar & 7 \\
Bilgiye ulaşım kolaylı̆̆ vardır & 4 \\
Yardımcı kaynak sağlar & 2 \\
İletişimi kolaylaştırır & 2 \\
Motivasyon kaynağıdır & 1 \\
Zaman tasarrufu sağlar & 1 \\
Öz değerlendirme sağlar & 1 \\
Kişisel gelişim sağlar & 1 \\
\hline
\end{tabular}

Tablo 5 incelendiğinde bloglarnn öğretmenler için z̧engin bir içerik deposu olduğu (n=11), fikir paylaşım (n=11), güncellik ( $n=7)$ ve bilgiye ulasmada kolaylhk sağladığ $(n=4)$, derslerle ilgili yardımo kaynak olduğu $(n=2)$ ve ögretmenler arasinda iletisimi kolaylastırdı̆̆ $(n=2)$ görülmektedir. Ayrica eğitim ile ilgili blogların motivasyon kaynă̆ı olduğu $(n=1)$, zaman tasarrufu sağladiğ $(n=1)$, öz dĕgerlendirme firsatı sunduğu $(n=1)$ ve kisisisel gelisime destek olduğ $(n=1)$ da katkilar arasinda sayılabilir.

Bu konuda Ö1 görüşlerini şu şekilde ifade etmiştir:

"Eğitim ile ilgili bloglarn geniş bir bilgi ă̆ olduğunu düsünüyorum. Bloglar sayesinde genis kitlelere bitap edilebilir, farkel yaklaşmlar ayn anda görülebilir."

Ö12 nin bu konudaki görüşlerini şu şekilde özetlemek mümkündür:

"Bloglar örnek doküman paylaşımı konusunda zengin bir içerik deposu olduğu gibi, kişisel gelisimim sürecimde artı ve eksilerimi görmek agısindan kizyaslama imkan sunuyorlar."

Ö16 ise şu şekilde görüş bildirmiştir:

"Takip ettiğim bloglarda farkh materyal, konu anlatumlar, etkinlik ve canlandirmalar takip ederek kendi derslerimi renklendiriyorum. Isslediğim konular ile ilgili testlere kolayca ulaşip, üzerinde değgsisiklikler yaparak

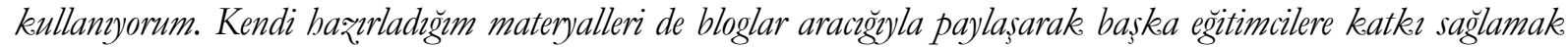
bana mutluluk veriyor."

\section{8. Öğretmenlerin eğitim ile ilgili blogların olumsuz yönlerine ilişkin düşüncelerinin incelenmesi}

Eğitim ile ilgili blogların olumsuz yönlerine ilişkin öğretmenlerin görüşleri sorulduğunda 6 öğretmen herhangi bir olumsuz yönü olmadığını, 16 öğretmen ise bazı olumsuzlukların olduğunu düşündüklerini ifade etmişlerdir. Tablo $\sigma^{\prime} d a$ bu olumsuz yönlerin neler olduğuna yer verilmiştir.

Aşağıda öğretmenlerin eğitim ile ilgili blogların olumsuz yönlerine dair düşüncelerine yönelik

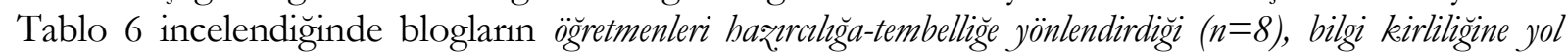

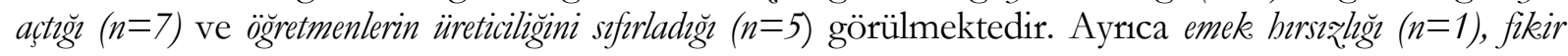


Tepe, N. (2020). Eğitim ile ilgili bloglar: Öğretmenlerin kullanım durumları ve düşüncelerinin incelenmesi. Journal of Human Sciences, 17(1), 162-171. doi:10.14687/jhs.v17i1.5766

dayatması ( $n=1)$ ve ögrencilerin smav sorularna ulaşması ( $n=1)$ gibi durumlar da olumsuz yönler olarak ifade edilmiştir.

Tablo 6. Eğitim ile ilgili blogların olumsuz yönleri

\begin{tabular}{ll}
\hline Olumsuz yönler & $\boldsymbol{n}$ \\
\hline Hazırc1lik-tembellik & 8 \\
Bilgi kirlilï̆i & 7 \\
Üreticiliği sıfırlaması & 5 \\
Emek hırsızlığ1 & 1 \\
Fikir dayatması & 1 \\
Öğrencilerin sınav sorularına ulaşması & 1 \\
\hline
\end{tabular}

Bu konuda Ö4 şu şekilde görüş bildirmiştir:

"Bazen bakayorsunuz bir konu hak.kinda gerekli gereksiz, bilgiler oluyor, bilgi kirliliğine yol açyor. Tartşslan konuya bakeyorsunuz ceviz kabuğunu doldurmayacak bir konu. Zaman zaman da bloglara içerik yükleyen insanlarn kendi fikirlerini kanun gibi dayattıklarm görüyorum."

Ö6'nın bu konudaki düşünceleri şu şekildedir:

"Bloglar aracliğgyla istedig̈imiz bilgive annda ulaşabiliyoru\%. Bu sekilde emek verilmeden hažr bilgive ulasmak bilginin kiymetini düşürdüğ̈̈ gibi belli bir süre sonra tembelliğe de yol açabiliyor. Ögrretmenlerin üreticiliğini stfirlyyor."

Ö11'in görüşlerini ise şu şekilde özetlemek mümkündür:

"Baz̨ ögretmenler yapacaklarn sinav için bloglardan aldıklar sorularn değgstirmeden kullanyor. Bu bloglar ögrencilerin kullammmna da açı olduğundan, ögrencinin sınav sorularnna ulaşması olumsuz sonuçlar doğurabiliyor."

\section{Tartışma ve Sonuç}

Öğretmenlerin eğitim ile ilgili bloglar hakkındaki düşüncelerini incelemeyi amaçlayan bu araştırmanın sonuçlarına göre katılımcıların tamamına yakınının alanlarıyla ilgili en az bir blog takip ettikleri sonucuna ulaşılmıştır. Bu bloglar arasında en çok takip edileni "egitimhane", "egitimpedia", "vitaminogretmen", "ilkokul" ve "morpakampus" adlı bloglardır. Bu blogların daha çok takip edilmesinin nedeni dersler için zengin içeriklere sahip olması ve öğretmenler arasında fikir paylaşımını sağlaması olabilir. Öğretmenler genelde haftada bir kaç gün sılklğında blogları takip ettiklerini ifade etmişlerdir. Öğretmenler bloglar dışında sosyal medyadan da kendi branşları ile ilgili içeriklerin yer aldığı grupları takip etmektedirler. Katılımcıların çoğu eğitimle ilgili herhangi bir basılı yayın takip etmemektedir. Gelişen ve değişen teknoloji dünyasında insanların bilgisayarları hatta elinin altında bulunan telefonları aracıllğıyla istedikleri bilgilere anında, zahmetsiz ve basılı yayınlara göre çok daha düşük ücretlerle ulaşabilmesi bu durumun nedeni olarak ifade edilebilir. Katılımciların eğitim ile ilgili blogları kullanım amaçları sorulduğunda çoğunlukla öğrencilerine ödev-proje vs konusu belirlemek için, yıllık-günlük plan hazırlamak için, alanı ve mesleği ile ilgili güncel gelişmeleri takip edebilmek için ve sınav soruları oluşturmak için takip ettikleri görülmüştür. Ayrıca bilgi ve birikimini paylaşmak için, vakit geçirmek için ve arkadaşları yönlendirdiği için takip ettiklerini ifade eden öğretmenler de olmuştur. Öğretmenlerin görüşlerine göre eğitim ile ilgili bloglar zengin bir içerik deposu olması, fikir paylaşımına imkan vermesi, güncel olması, bilgiye ulaşmada kolaylık sağlaması, kişisel gelişime katkı sağlaması, iletişimi kolaylaştırması, motivasyon kaynağı olması ve zaman tasarrufu sağlaması gibi özellikleri bakımından kendilerine katkı sağlamaktadır. Blogların yabanc1 dil öğretiminde kullanımına ilişkin öğretmen ve öğrenci görüşlerini inceledikleri çalışmasında Türker ve Genç (2018) blogların kullanımı kolay ve etkili araçlar oldukları, etkili ve etkileşimli öğrenme ortamları sunarak öğrencilerin öğrenmeye karşı tutumlarını olumlu yönde etkiledikleri, genel akademik başarıyı ve motivasyonu artıran bir öğrenme biçimi oldukları sonuçlarına ulaşmışlardır. Duffy ve Bruns (2006) ise blogların kişilerin eğitim-öğretim tecrübelerini yansıttı̆̆, kaynaklar ve yöntemler ile ilgili sınıflandırılmış açıklamalar içerdiği, mesleki zorluklar ile 
Tepe, N. (2020). Eğitim ile ilgili bloglar: Öğretmenlerin kullanım durumları ve düşüncelerinin incelenmesi. Journal of Human Sciences, 17(1), 162-171. doi:10.14687/jhs.v17i1.5766

ilgili çıkış noktaları sunduğu, teknoloji hakkında ipuçları içerdiği, etkinlikler, ödevler ve kaynaklarla ilgili zengin bir depo olduğu ve öğrencilerin değerlendirilmesi ile ilgili çevrimiçi bir alan olduğunu vurgulamışlardır. Araşırma kapsamında ulaşılan bir diğer sonuca göre hazırcılı̆ga alıştırması, bilgi kirliliğine yol açması, üreticiliği sıfırlaması, emek hırsızlığına yol açması, fikir dayatması hissine sebep olması ve öğrencilerin sınav sorularına ulaşabilmesi gibi faktörler ise öğretmenler tarafindan blogların olumsuz özellikleri olarak ifade edilmiştir. Benzer olarak Tonbuloğlu ve İşman (2014)'n çalışmasında bilgi kirliliği sosyal medyanın olumsuz yönleri olarak öğretmenler tarafindan vurgulanmıştır. Başka bir araştırmada ise blogların eğitim alanında yeni bir ortam sunmasının yanında siber zorbalık gibi internet suçlarına açık bir ortam oluşturmaya da yol açabileceği ifade edilmiştir (Özüdoğru, 2014).

\section{5. Öneriler}

Araştırma bulgularına göre öğretmenlerin eğitim ile ilgili bloglara yönelik ilgilerinin olduğu söylenebilir. Bu bağlamda en çok takipçisi olan blogların niteliği öğretmenlerin ilgi ve isteklerine yönelik olarak artıracak çalışma ve düzenlemeler yapilabilir. Bloglar için hazırlanan içerikler oluştururken alan uzmanlarının görüşü alınarak yanlış ve gereksiz bilgilerin önüne geçilebilir. Bloglarda sınav sorularının yer aldığı ilgili bölümlere öğrencilerin ulaşmasını engellemek adına öğretmenler için şifreli giriş sağlanabilir. Öğretmenlerin blog kullanımlarını teşvik etmek için eğitimler hazırlanabilir. Bu eğitimlerde blogların nasıl daha etkili kullanılabileceği ya da nasıl blog oluşturulabileceği anlatılabilir, daha az bilinen ve eğitime katkı sağlayacağ1 düşünülen blogların tanitımı yapilabilir.

\section{Kaynakça}

Baker, J. R., \& Moore, S. M. (2008). Blogging as a social tool: A psychosocial examination of the effects of blogging. CyberPsychology \& Behavior, 11(6), 2008, 747-749.

Dinçer, M. Z., Çakmak, T. F. ve Aydoğan Çiftçi, M. (2019). Turizm endüstrisinde blogların gücü ve turist rehberleri açısından bir değerlendirme. Türk Turiz̧m Araştırmalan Dergisi, 3(1):34-46.

Duffy, P., \& Bruns, A. (2006). The use of blogs, wikis and rss in education: A conversation of possibilities. Proceedings Online Learning and Teaching Conference, 31-38. Retrieved May 15, 2019, from https://eprints.qut.edu.au/5398/1/5398.pdf

Efimova, L. (2009). Passion at work: Blogging practices of knowledge workers. Novay $\mathrm{PhD}$ Research Series No:24, Netherlands.

Hargreaves, A. (2002). Sustainability of educational change: The role of social geographies. Journal of Educational Change, 3(3-4), 189-214.

Hsu, C-L., \& Lin, J-C. (2008). Acceptance of blog usage: The roles of technology acceptance, social influence and knowledge sharing motivation. Information \& Management, 45, 65-74.

Lewis, G. (2009). Bringing technology into the classroom. Oxford: Oxford University Press.

Madge, C., Meek, J., Wellens, J., Hooley, T. (2009). Facebook, social integration and informal learning at university: 'It is more for socialising and talking to friends about work than for actually doing work'. Learning, Media and Technology, 34(2), 141 - 155.

Moralı, G. (2018). Yabancı dil olarak Türkçe öğretiminde blogların kullanımına yönelik kuramsal bir çalışma. Turkphone, 1(1), 41-50.

O'Reilly, T., (2007). What is web 2.0: Design patterns and business models for the next generation of software. Communications \& Strategies, 65(65),16-37.

Öztürk, D. S., Öztürk, F. \& Özen, R. (2016). Öğretmenlerin sosyal medya araçlarını mesleki gelişim amaçlı olarak kullanım durumları. International Journal of Human Sciences, 13(1), 7-21. doi:10.14687/ijhs.v13i1.3515.

Özüdoğru, Ş. (2014). Bir web 2.0 uygulaması olarak bloglar: Blogların dinamikleri ve blog alemi. The Turkish Online Journal of Design, Art and Communication - TOJDAC, 4(1), 36-50. 
Tepe, N. (2020). Eğitim ile ilgili bloglar: Öğretmenlerin kullanım durumları ve düşüncelerinin incelenmesi. Journal of Human Sciences, 17(1), 162-171. doi:10.14687/jhs.v17i1.5766

Patton, M. Q. (2014). Nitel araștırma ve değerlendirme yöntemleri. (Çeviri Ed. M. Bütün \& S. Beşir). Ankara, Pegem.

Seçer, H. S. (2017). İnsan kaynakları alanına bloglar üzerinden bakmak nitel bir inceleme. Yönetim ve Ekonomi, 24(3), 759-782.

Tonbuloğlu, İ. \& İşsman, A. (2014). Öğretmenlerin sosyal ağları kullanım profillerinin incelenmesi. Bartı Üniversitesi Ë̆gitim Fakültesi Dergisi, 3(1), 320 - 338.

Türker, M. S. ve Genç, A. (2018). Yabancı dil olarak Türkçe öğretiminde blogların öğretim amaçlı kullanımı üzerine öğrenci ve öğretmen görüşleri. SEFAD, 39, 251-266.

Ward, Jason M. (2004 ). Blog assisted language learning (BALL): Push button publishing for the pupils. TEFL Web Journal, 3(1), 1-16.

Yıldırım, A. \& Şimşek, H. (2008). Sosyal bilimlerde nitel araștırma yöntemleri. Ankara: Seçkin.

\section{Extended English Summary}

\section{Problem Situation}

Education related blogs are the social areas, where sharing knowledge and experience; school, student, family, parents, course contents, current developments in education and other issues related to education and training materials are published. These blogs are a rich source of information for teachers, administrators, parents and even students. In this context, education blogs provide users with easy and fast access to up-to-date information, improves collaboration, gives insights to different ideas, and gives them the opportunity to make self-evaluation. According to Hargreaves (2002), educational networks support change and the sustainability of change, social and professional networks connected to users via the Internet are connected to each other through interaction and sharing of information, and over time this situation can turn into professional support. In the Turkish literature, the lack of studies on educational blogs with a large impact area and wide usage has led to the need for research on this subject. For this purpose, it was aimed to examine the opinions of teachers about blogs about education.

\section{Aim of the Study}

The aim of this study is to examine teachers' use of educational blogs and their opinions about these blogs. The study used the following research questions in order to find answers to the main problem:

1. Do teachers follow any educational blogs?

2. How often do teachers follow educational blogs?

3. Which blogs do teachers follow?

4. What are the characteristics of blogs that teachers follow?

5. Do teachers follow any printed publications on education?

6. What are the positive aspects / contributions of educational blogs according to teachers' views?

7. What are the negative aspects of blogs about education according to teachers' views?

\section{Method}

The research was carried out according to the phenomenon pattern of qualitative research methods. The aim of phenomenology is to focus on phenomena that we are actually aware of but do not have in-depth and detailed understanding of (Yıldırım \& Şimşek, 2008).

The study group consists of 22 teachers. 12 of the participants were female and 10 were male. The ages range from 22 to 40 years. Their professional seniority is between $0-5$ years and the highest is 16-20 years. They are classified as pre-school teacher (1), class teacher (10) and branch 
Tepe, N. (2020). Eğitim ile ilgili bloglar: Öğretmenlerin kullanım durumları ve düşüncelerinin incelenmesi. Journal of Human Sciences, 17(1), 162-171. doi:10.14687/jhs.v17i1.5766

teacher (11) according to their branches. Almost all of the teachers have undergraduate degrees and only one teacher has a master degree.

Data were collected using a semi-structured interview form developed by the researcher. The data obtained within the scope of the research were analyzed with descriptive analysis technique (Yıldırım \& Şimşek, 2008), which is used in qualitative researches and aimed at presenting the data to the reader systematically and clearly. The analyzed data are presented with frequency and tables. The opinions of the participants were coded as T1, T2 and presented as direct citations in order to increase the reliability of the study.

\section{Results}

According to the results of this study which aims to examine teachers' opinions about education blogs, it is concluded that almost all of the participants follow at least one blog about their field. The most popular of these blogs are "egitimhane", "egitimpedia", "vitaminogretmen", "elementary school" and "morpakampus". The reason why these blogs are more followed is that they have rich content for the lessons and they can share ideas among the teachers. Teachers stated that they usually follow blogs a few days a week. In addition to blogs, teachers follow groups of social media related content. Most of the participants do not follow any educational publications. In the developing and changing world of technology, people can access the information they want via their computers or even their phones instantly, effortlessly and at much lower prices than printed publications. When asked about the intended use of participants' blogs on education, it was seen that they follow up the blogs to determine the subject of homework-project, etc., to prepare an annual-daily plan, to follow current developments in the field and profession and to create exam questions. According to the opinions of teachers, blogs related to education contribute to their characteristics such as being a rich content store, sharing ideas, being up to date, facilitating access to information, contributing to personal development, facilitating communication, being a source of motivation and saving time. According to another conclusion reached in the scope of the research, teachers 'negative characteristics of blogs were expressed by teachers such as practice of preparing, causing information pollution, resetting production, leading to theft of labor, causing the feeling of imposing ideas and reaching students' exam questions.

\section{Suggestions}

According to the findings of the research, it can be said that teachers are interested in blogs related to education. In this context, the quality of blogs, which have the most followers, can be increased according to the interests and desires of teachers. When creating content prepared for blogs, it may prevent the wrong and unnecessary information by taking the opinion of the field experts. Bloglarda sınav sorularının yer aldığı ilgili bölümlere öğrencilerin ualşamasını engellemek adına öğretmenler için şifreli giriş sağlanabilir. Trainings can be prepared to encourage teachers to use blogs. In these trainings, how to use blogs more effectively or how to create blogs can be explained, less known and thought to contribute to education can be promoted blogs. 